\title{
How to Achieve Local Resilience to Flood Risks by Increasing Solidarity: The Example of the "Syndicat Mixte" (Inter-Municipal Cooperation Structure) of the French Territory of Belfort-Montbéliard
}

\author{
Pierre Pech1, Charly Duplan'1, Lucas Robin-Chevallier ${ }^{1}$, Remy Fevrier ${ }^{2}$ \\ ${ }^{1}$ University of Paris 1 Panthéon-Sorbonne, Paris, France \\ ${ }^{2}$ National Conservatory of Arts and Crafts (CNAM), Interdisciplinary Laboratory of Action Science Research \\ (LIRSA), Paris, France \\ Email: pech@univ-paris1.fr
}

Received 30 December 2015; accepted 26 April 2016; published 29 April 2016

Copyright (C) 2016 by authors and Scientific Research Publishing Inc.

This work is licensed under the Creative Commons Attribution International License (CC BY). http://creativecommons.org/licenses/by/4.0/

c) (i) Open Access

\begin{abstract}
This paper illustrates approaches to flooding risk governance in a territory where a high density of population corresponds to a high level of industrial activities and a significant development of transport infrastructures in a transboundary context between France, Germany and Switzerland. In the last few years, some fundamental changes in European official instructions about risks and especially about flooding risks occurred. Substantial public policy challenges remain in order to promote a broad-based resilient territory twinned with local knowledge of sustainable land management and civic participation in local governance. The survey is based on a GIS study and questionnaires with a representative panel of 235 stakeholders from the studied territory. Our statistical results demonstrate that, in spite of a deep-rooted mindset as regards flooding hazards, local population awareness of the territorial vulnerability is not related to important challenges. A hierarchical analysis of the data shows that the awareness of stakeholders is less related to the importance of risks when the territorial level decreases. It also highlights the decline of solidarity among neighbouring communities when the distance from the industrial axis increases. Greatly impacted by flooding risks, industrial activities of the regional basin are paradoxically not really perceived as common challenges. Such a case study illustrates how public policies need to be relevant to the adapted levels. Awareness of common issues is a central target to develop acceptance in order to provide an efficient framework of resilience, including willingness to pay to reduce the risk and solidarity in local development compensations.
\end{abstract}


Keywords

Territorial Resilience, Flooding Management, Public Policies, Territorial Solidarity

\section{Introduction: Aims and Scope}

This study is the result of a commission from the French regional authority of the Franche-Comté region, the "DREAL", Direction Régionale de l'Environnement, de l'Aménagement et du Logement, (French regional directorate for environment, planning and housing) [1]. This public commission concerns an appraisal of the comprehension of the capacity and efficiency of Territorial Tools of Land Management (TTLM) by stakeholders and their impact on resilience against flood risks [2]-[4].

In fact, this study comes in a general context of changes in public policies concerning risks especially within the European countries [3]. Numerous and active public policies concerning flood management within the European Union (following the 2007/60/EC Directive) are often related to international decisions like the recent conference of Hyogo on natural disaster prevention. As shown in scientific literature [5]-[8], management agencies have conducted for a long time proactive risk prevention policies generally inscribed within institutional areas, in territories, at local as at national scale. Local hazard management aims to obtain a better knowledge and awareness of risks as previously done for the constitution of natural conservation areas [9]-[11]. Thus this evolution is related to a global context of water policy [12].

In France, the Barnier Act of 1995 (Law no. 95-101) provides an institutional framework with the "Plan de Prévention des Risques" (PPR or plan to manage the prevention of risks). A PPR is a local tool usefully integrated into urban planning decisions taken by local councils when the national authority requires it. However, relations between these Territorial Tools of Risk Prevention (TTRP) and land management policies are well known. Most of the research literature highlights the means to perform the analysis of risks more than the efficiency of these policies [13]-[16]. However, recent news about natural disasters point out the necessity to upgrade these policies to understand how to improve the resilience of the territories against flood risks [3] [4] [11] [17].

Emergency Management considers resilience essential for safeguarding communities or building safer communities. The goal of disaster risk management is to guarantee minimal loss of life and livelihoods and to allow the affected community or system to return to "normal" within the shortest possible time [11]. The resilience definition adopted here is: "a process linking a set of adaptive capacities to a positive trajectory of functioning and adaptation after a disturbance" [18]. As shown in current literature [19]-[23] resilience can be defined and measured by focusing on three attributes: maintenance of structure and function in the face of disturbance, ability to self-organize in response or anticipation to disturbance and capacity for learning and adaptation. Prosser and Peters [18] claim that to support a disaster-resilient community, studies must focus on prevention, preparedness, response and recovery. In the case of territorial systems, these attributes integrate the understanding and the awareness of the population and especially stakeholders managing the territory [24]. Risk and territorial tools perception and awareness are huge parameters of resilience [16] [18] [21].

Because of the European legislation and its different enforcement provisions in national policies (Table 1), frameworks and methodologies of practitioners influence the way to enhance the resilience of territories [25]. Moreover, progress in land and flood management is not made to create new methods or theories but it may lead to an appropriate use of existing ones, indicating a need for simpler methods that provide satisfactory results.

A researcher trying to develop suitable methods for practical use should be conversant with the daily context of risk management practitioners [8]. Thus, knowledge of the range of territorial tools [25] is certainly one main way to upgrade the resilience against flood risks, and points out the question of acceptance [26] and perception [27]. Finally, there are few empirical and local studies of risk analysis [8], and it seems to be the same concerning an evaluation of TTLM and TTRP.

In order to document the relations between these territorial tools and the ability of local authorities to achieve resilience, the study focused on a very representative territory specifically impacted by flood hazards. Conducted through questionnaires, this paper is organized as follows: Section 2 presents the studied field, Section 3 the methods used to evaluate the level of knowledge and the deficiencies, Section 4 the results. In Section 5, the 
Table 1. Complex organisation in land management documents in France.

\begin{tabular}{|c|c|c|c|c|c|}
\hline \multicolumn{2}{|c|}{ Document name } & \multirow{2}{*}{ Scale } & \multirow{2}{*}{ Description } & \multirow{2}{*}{ Example(s) } & \multirow{2}{*}{ Reference law } \\
\hline French name & Translation & & & & \\
\hline \multicolumn{6}{|c|}{ Global documents } \\
\hline $\begin{array}{l}\text { Document départemental } \\
\text { des risques majeurs } \\
\text { (DDRM) }\end{array}$ & $\begin{array}{l}\text { Major risks } \\
\text { county document }\end{array}$ & $\begin{array}{l}\text { each } \\
\text { county }\end{array}$ & $\begin{array}{l}\text { Informative document for the local } \\
\text { population and authorities explaining } \\
\text { appropriate conduct and past events. It } \\
\text { summarizes information about risks and } \\
\text { lists the towns subjected to major ones. }\end{array}$ & $\begin{array}{l}\text { DDRM of } \\
\text { Belfort }\end{array}$ & $\begin{array}{l}\text { Art. R. 125-11 } \\
\text { (environmental } \\
\text { code) }\end{array}$ \\
\hline $\begin{array}{l}\text { Plan communal de } \\
\text { sauvegarde (PCS) }\end{array}$ & $\begin{array}{l}\text { Municipal } \\
\text { protection } \\
\text { document }\end{array}$ & town & $\begin{array}{l}\text { Mandatory municipal document } \\
\text { subjected to PPR describing crisis } \\
\text { management and actions of each } \\
\text { stakeholder. }\end{array}$ & $\begin{array}{l}\text { PCS of } \\
\text { Sochaux }\end{array}$ & $\begin{array}{l}\text { Art. L. 731-3 } \\
\text { (homeland } \\
\text { security code) }\end{array}$ \\
\hline \multicolumn{6}{|c|}{ Specific documents on flood risk } \\
\hline $\begin{array}{l}\text { Plan de prévention } \\
\text { du risque inondation } \\
\text { (PPRI) }\end{array}$ & $\begin{array}{c}\text { Flood risk } \\
\text { prevention } \\
\text { document }\end{array}$ & $\begin{array}{l}\text { each town } \\
\text { in basin }\end{array}$ & $\begin{array}{l}\text { Imposes public easements, i.e. } \\
\text { obligations for construction } \\
\text { against flooding. }\end{array}$ & $\begin{array}{l}\text { PPRI of the } \\
\text { Savoureuse or } \\
\text { Bourbeuse rivers }\end{array}$ & $\begin{array}{l}\text { Art. 95-101 of } \\
\text { Barnier Act }\end{array}$ \\
\hline Atlas de bassin & Basin atlas & $\begin{array}{l}\text { each basin } \\
\text { subjected to } \\
\text { risks }\end{array}$ & $\begin{array}{l}\text { Former PPRI but without easement, } \\
\text { it presents flood risks with maps }\end{array}$ & $\begin{array}{l}\text { Atlas of the } \\
\text { Douce basin }\end{array}$ & $\begin{array}{l}\text { SDAGE } \\
\text { additional } \\
\text { information }\end{array}$ \\
\hline \multicolumn{6}{|c|}{ River management documents } \\
\hline $\begin{array}{l}\text { Schéma (départemental) } \\
\text { d'aménagement et de } \\
\text { gestion des eaux } \\
\text { (S(D)AGE) }\end{array}$ & $\begin{array}{l}\text { (County) planning } \\
\text { and water } \\
\text { management } \\
\text { scheme }\end{array}$ & basin & $\begin{array}{l}\text { Determines water resource } \\
\text { management in accordance with } \\
\text { the principles of the Water Act. }\end{array}$ & $\begin{array}{l}\text { SDAGE of } \\
\text { Rhin-Meuse }\end{array}$ & $\begin{array}{l}\text { Art. } 92-3 \text { of } \\
\text { Water Act }\end{array}$ \\
\hline Contrat de rivière & River contract & basin & $\begin{array}{l}\text { Voluntary agreement with same aims as } \\
\text { S(D)AGE without regulatory scope. }\end{array}$ & $\begin{array}{l}\text { Allan river } \\
\text { contract }\end{array}$ & I \\
\hline \multicolumn{6}{|c|}{ Planning documents } \\
\hline $\begin{array}{l}\text { Schéma de cohérence } \\
\text { territoriale (SCOT) }\end{array}$ & $\begin{array}{l}\text { Territorial } \\
\text { cohesion scheme }\end{array}$ & $\begin{array}{l}\text { Association } \\
\text { of county } \\
\text { councils }\end{array}$ & $\begin{array}{l}\text { Gives planning directives } \\
\text { (risks poorly developed) }\end{array}$ & $\begin{array}{l}\text { SCOT of Pays } \\
\text { de Montbéliard }\end{array}$ & $\begin{array}{l}\text { Art. L. 122-1 } \\
\text { (planning code) }\end{array}$ \\
\hline $\begin{array}{l}\text { Plan local d'urbanisme } \\
\text { (PLU) }\end{array}$ & Local urban plan & town & $\begin{array}{l}\text { Mandatory document that must be in } \\
\text { compliance with SCOT and integrates } \\
\text { PPRI; it plans zones that are not suitable } \\
\text { for development and subjected to risks. }\end{array}$ & $\begin{array}{l}\text { PLU of } \\
\text { Montbéliard }\end{array}$ & $\begin{array}{c}\text { Art. L. } 123 \\
\text { (planning code) }\end{array}$ \\
\hline
\end{tabular}

results are discussed with a special focus on possible implications of the conclusions.

\section{Location of the Study-Geographic Area Scope and Nature of Risks}

The target territory is the Urban Area of Belfort-Montbéliard-Delle-Héricourt (UABMDH) neighbouring Switzerland (Figure 1). It is well known because it is the manufacturing area of the Peugeot Company, it is a territory marked by strong issues related to prevention of flooding. Located between the Vosges and Jura mountains, the region belongs to a threshold area corresponding to an inlaid limestone plateau in the south, sandstone plateaus in the north and small, mostly alluvial, plains.

The hydrographic network is traversed by rivers whose flows are generally not weighted and marked by an interannual irregularity. If water seems abundant in these fluvial axes, they are often oriented towards spasmodic conducts. Without being torrential, they are predisposed to large variations of flow resulting in floods and overflows that the current climate change trends reinforce. Flooding seems to be one of the frequent features of fluvial dynamics for rivers with strong anthropic floodplains.

The hydrographic system is highly hierarchized within the urban area and dominated by the Allan, the Doubs and the Savoureuse rivers that converge around the city of Montbéliard. This hydrologic network consists of a 


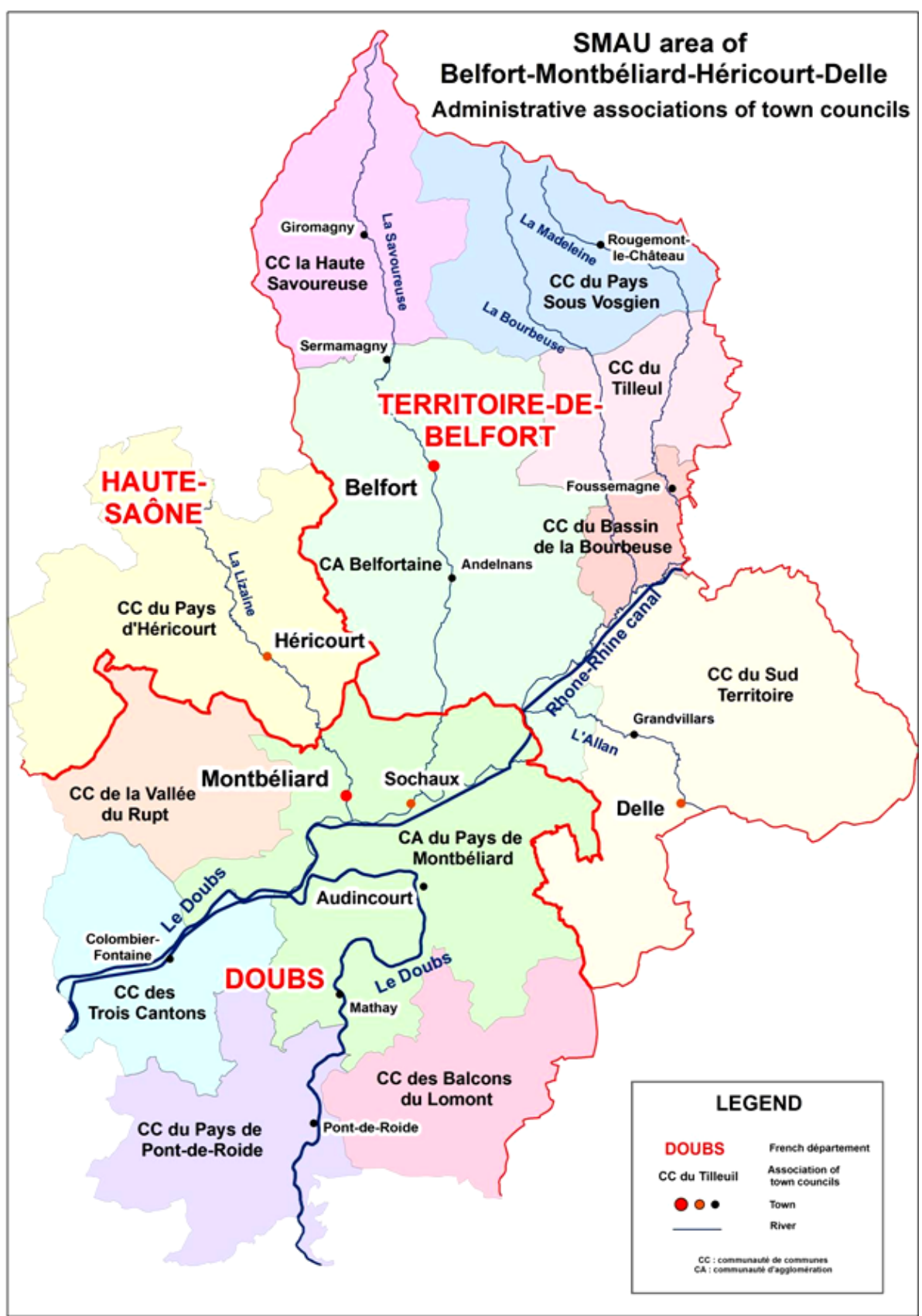

Figure 1. Map of Urban Area of Belfort-Montbéliard-Delle-Héricourt, so called in French SMAU area of Belfort-Montbéliard-Héricourt-Delle Inter-municipality councils.

set of highly ramified valleys or channels flowing in wide floodplains. In fact, there is a real convergence of the river system towards Montbéliard that increases the risk of flooding in the UABMDH area.

With 307,666 inhabitants in 2007 for $1240.5 \mathrm{~km}^{2}$ and with 199 towns [1], the density of the area is more than twice the French average density with 248 inhabitants $/ \mathrm{sq} \cdot \mathrm{km}$. This high density is related to the large number of medium-sized and small cities and reinforced by a rural scattered settlement where minimum densities are rarely below 50 inhabitants/sq. km. It could be explained by the presence of major firms like Peugeot or Alstom and their industrial plants. The 1990’s flood cost €300 million, especially because of damage caused to their infrastructures. Consequently, €30 million were invested by local authorities to prevent future floods from occurring $[1]$. 
Otherwise, as already and most often demonstrated [28] [29], urbanization in areas like UABMDH increases the risk of flooding. Furthermore, our survey underlines a real culture of flooding and its management throughout the territory. The question is how to improve the efficiency of territorial tools evaluated by local stakeholders in order to maintain and improve territorial resilience.

\section{Methods}

The aim of our method is to evaluate what are the perceptions of risks due to flood. This aim is integrated in a global diagnosis of the resilience of the territory (Figure 2) [1]. The basis of this method requires conducting an investigation of how the populations and especially public policy makers or contributors appreciate:

- Risks, due to floods,

- Direct risks due to local flooding events,

- Systemic risks, due to the consequences of the public territorial policies, specialized in flooding management and other ones,

- The efficiency of these policies.

As shown in Table 1, there is a complex organisation in land management documents. Our aim was to evaluate knowledge of these documents by local stakeholders and particularly by policy makers. The method used is to develop a diagnosis protocol for a territory by investing in previously collected data but also by immersing ourselves in the territory in order to meet a range of local actors (Figure 2). The aim of this immersion is to form an idea of ways of perception and appropriation of the territorial instruments so called public policies tools by the stakeholders of the community as defined by Boon et al. [23].

First of all, the study gathered data about the demographic compositions, the economic activities and the location of all 199 towns in the area [1]. Conventional data drawn from statistical resources from the French national institute, INSEE, made it possible to determine backgrounds in order to provide statistical studies [1]. From this panel of 199 towns, we selected 88 in order to provide personal interviews with stake holders (Table 2). The choice of the 88 towns is related with the composition (demographic, localisation from floodplains, public policies tools) of the 199 with respect of the best representativeness of our sample [1]. 235 stakeholders provide statistical is a line and is integrated to a town of the 88 of the area. Our study is designed as a qualitative questionnaire transformed in a quantitative study. We collected data in the field in November 2012: 31 persons provided the questionnaires of the 235 respondents.

We also used a GIS analysis in order to value the location of each local town in order to underline whether it is relevant to flooding hazards. The most simple and relevant criterion is the distance of the town, and especially its core, from the axis of the floodplain [30]. The analysis done of these elements of backgrounds was translated into an index:

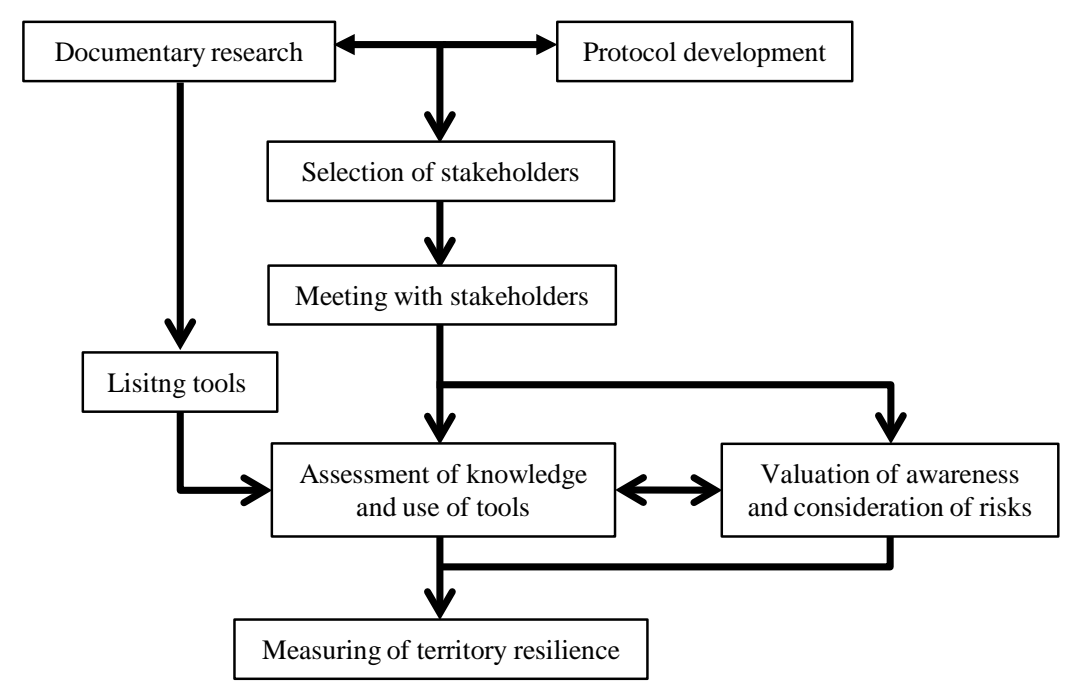

Figure 2. Methodology to lead a diagnostic of resilience capability of territorial stake holders. 
Table 2. Summary of interview schedule.

\begin{tabular}{|c|c|}
\hline \multirow{5}{*}{$\begin{array}{l}\text { Territorial exposure } \\
\text { to flood risks }\end{array}$} & $\begin{array}{l}\text { Definition and local issues } \\
\text { How do you define hazards, especially flood risks? } \\
\text { Is your territory exposed to flood risks? } \\
\text { Has it been declared stricken by a natural disaster? } \\
\text { How do you understand the concept of vulnerability? What do you consider to be vulnerable in } \\
\text { your territory? Are there activities which may represent a significant vulnerability to flood risks? }\end{array}$ \\
\hline & Limits \\
\hline & When do you consider being impacted by floods? \\
\hline & $\begin{array}{l}\text { Risk memory } \\
\text { Do you remember any local disaster? } \\
\text { In your opinion, does the frequency of floods change? Why? }\end{array}$ \\
\hline & $\begin{array}{l}\text { Local solidarity } \\
\text { Did floods occur in neighbouring territories? } \\
\text { Before delivering a construction permit, do you study the impacts on neighbouring areas? } \\
\text { Have you made a vulnerability diagnosis of public equipment? }\end{array}$ \\
\hline \multirow{2}{*}{$\begin{array}{l}\text { Risk prevention } \\
\text { management }\end{array}$} & $\begin{array}{l}\text { Risk management } \\
\text { How do you include water issues in your projects? } \\
\text { How do you adjust the risk management scale to your local issues? }\end{array}$ \\
\hline & $\begin{array}{l}\text { Willingness to pay } \\
\text { Do you want to pay more to reach a better risk management level? }\end{array}$ \\
\hline \multirow{3}{*}{$\begin{array}{l}\text { Prevention tools } \\
\text { relevance }\end{array}$} & $\begin{array}{l}\text { Tools } \\
\text { What tools do you use for risk prevention? } \\
\text { Who creates these tools? Under what conditions do you have access to these tools? }\end{array}$ \\
\hline & $\begin{array}{l}\text { Their effectiveness } \\
\text { Are these tools efficient? Why? } \\
\text { What do you propose to improve them? } \\
\text { Is a new tool necessary? }\end{array}$ \\
\hline & $\begin{array}{l}\text { Tools implementation } \\
\text { Which tools do you use to return to a normal situation? How quickly? } \\
\text { Who is in charge of the implementation of these tools? } \\
\text { Does someone help you to implement tools for risk prevention? } \\
\text { How do you communicate to the population about risks and their management tools? }\end{array}$ \\
\hline
\end{tabular}

$$
\lambda \text { Index }=(\beta / 2) \times(\log \delta / 2)
$$

where $\beta$ is the shortest distance of the town from floodplains and $\delta$ is the total population of the local community. In order to smooth the values, we added coefficients. The largest demographic size of the towns is related to the proximity to a river: the biggest cities such as Belfort (50,128 inhabitants), Montbéliard (25,974 inhabitants), Sochaux (4027 inhabitants), etc. are near the flooding plains of Savoureuse and Doubs (Figure 1 and Figure 3). On Figure 3, is represented the relation between the population of the towns with their distance to a floodplain: this relation is weak $\left(\mathrm{R}^{2}=0.3\right)$ but it is significant. Because flooding areas are especially near rivers, we gave more weight to the location. Thus, in order to show the impact of proximity in the vulnerability evaluation, the $\lambda$ Index gives a more significant value of the distance from a floodplain than the population.

After taking into account the context of the UABMDH and its vulnerability issues and gathering a collection of statements from local actors, it is possible to:

- Evaluate the panel of territorial and regulatory tools (like PPR) and other implemented territorial tools used for example for planning,

- Evaluate the level of appropriation and inclusion of these tools,

- Evaluate the level of awareness and consideration of flooding and drought hazards.

Stakeholders were identified using in formations obtained from DREAL. We contacted the stakeholders by mail and then by telephone in order to arrange a time for a face-to-face interview. The basis of our research was not just a questionnaire sent out but a real interview. The questionnaire was used to approach respondents' perceptions of risks and of tools to plan the prevention. Initially more than 500 stakeholders were contacted for an interview. Finally, the panel concerned 235 persons representative of the local population and especially public stakeholders (Table 3) and the sample of the stake holders concerned the 88 towns. All items of the questionnaire were pretested with students (see acknowledgements). Based on pretested results, items were rejected and 


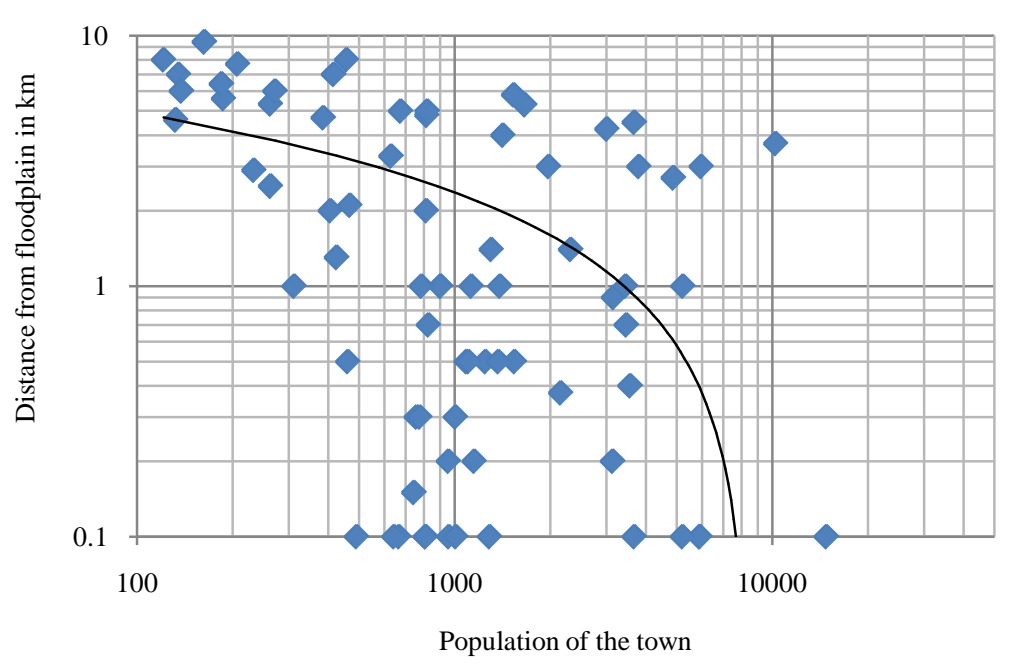

Figure 3. Relationship between the size of the population of towns and the distance from a floodplain $\left(Y=1.11 \ln (x)+10.03\right.$ and $\left.R^{2}=0.3208\right)$.

Table 3. Percentage of types of the 235 stakeholders surveyed for this study.

\begin{tabular}{cc}
\hline Types of stakeholder & Percentages \\
\hline Mayor and town councillor & $45 \%$ \\
Inter-municipality representative or county councillor & $14 \%$ \\
Inhabitant & $11 \%$ \\
Member of an association & $8 \%$ \\
Technical risk manager & $22 \%$ \\
\hline
\end{tabular}

new items were included. The research utilized a three-contact procedure: initial mailing, telephone contact for appointment and local interview. 31 persons_-students and teachers-did the interviews for two weeks in the field. Every interview was conducted in the UABMDH area. The words and statements were coded as " 0 " or "1", which made it possible to produce statistics [1]. Especially it was possible to provide the index of vulnerability with the answers of the stake holders as explained lower.

One of the study aims is to understand awareness of environmental policies by stakeholders involved in local management or activities. A questionnaire including nine topics was submitted to 235 different stakeholders to measure flood risk awareness (Table 3). Nonetheless, it implied that the population has a significant appreciation of hazards, both local and global.

The data collected by means of questionnaires were transformed into statistical values. For example, the feeling of vulnerability was classified into 5 levels, from $1=$ very low feeling of vulnerability, to $5=$ strong feeling of vulnerability. Such an index is the mix of three parameters determined by the questionnaire:

- Knowledge or perception of the frequency and intensity of floods on the territory,

- Feeling of vulnerability of the territory due to local flood hazards,

- Appreciation of global risks due to consequences for the local territory.

The value of the index is the mean value of these three approach of the vulnerability for each stake holders.

This paper focuses on the risks, and two questions are studied: how local stakeholders evaluate whether their town may be concerned by floods and, on the other hand, whether they know and appreciate usual tools of public policies, as shown in Table 1.

\section{Results}

Most of our questionnaires were submitted to local representatives followed by administrative workers, private workers, inhabitants and association members (Table 3). In total, 235 respondents correspond to 88 towns and 
local councils selected on the 199 ones of the territory. The work sought to explore the opinions and perception of stakeholders in the reality of flood and in the efficiency of policies. Other parameters like social composition of the sample, natural local features of the town, etc., were not significant. As previously mentioned, the survey concerns more rural towns and their councils than major urban areas. Regarding the awareness of useful territorial tools to fight flood risks, TTRP is the most cited set of tools (54.5\%). Such perception reveals the predominance of local risks.

A GIS analysis revealed that flood hazards occurred in valleys where industrial areas are concentrated [30]. Also, a statistical comparison of several values concerning relations between parameters led to reveal how the population feels vulnerable to flood hazards considering the distance from the valleys or the size of the community population. More precisely, there is a broad relationship between the perception of vulnerability and the kind of local target. Figure 4 shows this relationship between the value of the perception and the index summarizing the backgrounds, especially the distance from a floodplain and the size of the population of the town. There is no understanding of the consequences of catastrophic floods in industrial valleys for more rural communities, in terms of economy, employment, etc.

\section{Discussion and Conclusion}

Our study investigated whether environmental policy beliefs and especially concerning flood risks may make it possible to underline the resilience capabilities of a territory [7] [25]. The study demonstrated the following:

- In spite of a good overall knowledge of local issues linked to the hydrological behaviour of rivers, there is a differential sensitivity of the interviewees when it comes to hazards and risks based on proximity, spatial distance and frequency of the event.

- The fragmented and discontinuous knowledge of scales and different issues (according to the scales) from the interviewees is one of the crucial points of the investigation.

- Many territorial tools exist in the area and remain effective for the most part, at every level they are planned for.

- The complexity of these tools and their different issues in terms of spatial scale levels blurs the knowledge of the interviewees and constitutes an obstacle to the process of resilience.

- The deficiency of territorial solidarity, the whole idea of territorial solidarity (because of interdependencies between territories), but also the types of stakeholders are all elements that leave questions about culture of risk and more widely about natural representation of the territory by interviewees. Our results show weak values of the perception of risks by stake holders. In particular local stake holders do not perceive the significance of common targets. The neighborhood attributes solidarity positively affect the resilience of the territory to flood risks.

Such an example is an illustration of a classical situation in which towns and industrial areas are often located in low-lying areas near rivers, where floodplains serve as conduits twinned with infrastructures for commerce

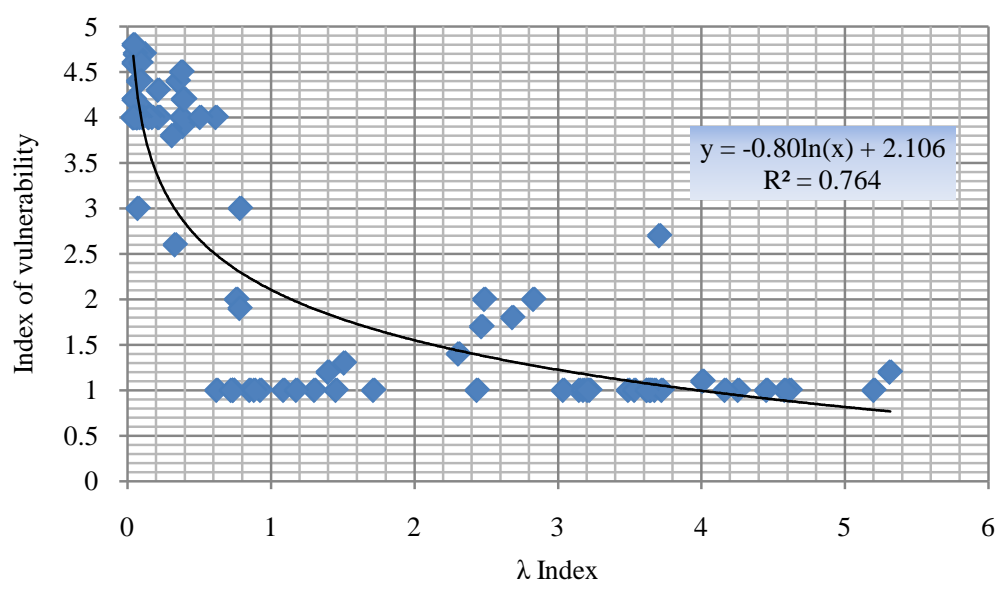

Figure 4. Relationship between mean value of vulnerability perceived by stakeholders and the value of the index of demographic size and distance from a floodplain. 
between other regions [30]. The concentration of population and activities is an historical inherited situation. Consequently, within such a territory, but also in other similar ones, the collective search for strategies for sustainable development must meet questions of issues and risk management. Moreover, a control of planning and a development of information about risk importance based on finding what is considered as common heritage must be implemented in order to ensure a territorial equity. The successful implementation of such a program requires the ability to understand public needs, a degree of innovation and willingness to adopt a problem-solving approach. As stated by Winter and Bromhead [26], willingness is a qualitative measure of risk acceptance but risk acceptance is related to risk remediation and mitigation, especially by public policies [31]. One key factor is the connection across diverse local councils in order to increase local solidarity. In other situations, Hovardas and Poirazidis [32] have found contradictions between stakeholder beliefs and choices of public policies concerning protected area management. The aim of their study was to examine beliefs in order to understand the potential social consensus about environmental management. In our case, the Urban Area of BelfortMontbéliard-Delle-Héricourt, UABMDH, we saw that stakeholders expect a better land management. In the same way, they also expect a better participation, whose benefits are the increase of territorial solidarity and environmental awareness, as shown by several authors [7] [33]-[36]. Sample demographics did not influence results but environmental awareness is more or less related to the real risks: the highest potential of floods, near the fluvial floodplains, determines the strongest demand for efficient land management tools. The core of the question is the capability of solidarity in a territory where vulnerabilities are broadly geographically concentrated. As shown by Rudel [37], cumulative benefits are related to the local and more global environmental awareness. As shown by Chia [38] and Prosser and Peters [18], the resilience may be the "way through wich communities can build their capacity [18]. As claimed by Prosser and Peters [18], the regional inquiry of local consensus increase the efficiency of risk and disaster management policies. For a resilience approach, local communities are more capable to provide a collective preventive action. In such circumstances, flood prevention may be related to local urban management that integrates global environmental management.

In fact, due to the European and French public policies, local stakeholders integrate both of these targets of land planning and territorial solidarity. In Europe, the European Water Framework Directive underlines that risk management is related to a global approach of the good ecological status of aquatic ecosystems. Good floodplain maintenance is seen as the restoration of the multifunctionality of rivers [39] [40].

The Urban Area of Belfort-Montbéliard-Delle-Héricourt, UABMDH, integrates land management of water basins but it also promotes broad-based civic participation in local governance. For example, councils, gathered together in the UABMDH, successfully commissioned a housing scheme on risk management. This required the acquisition of areas in the floodplain, especially near the industrial sector of Sochaux-Montbéliard, where Peugeot Company factories are located. These areas were transformed into natural reserves, Natura 2000 reserves, in order to increase drainage capacity for flooding events. As stated by Hassel (2012), risk management needs to be regarded and analysed as a system. Both approaches seem needed in order to increase the resilience of such complex territories: maintenance of multifunctionality of floodplains and participation of the stakeholders.

Our study was designed as a qualitative questionnaire transformed in quantitative data. We confirmed that the collective resilience of an area depends on stakeholders knowledge of the environmental system [24] [41] and public policies and tools [16] [18] [21] [42]. For public manager, the question of the information is essential. The resilience may be approached as a global way with and through social networks and social interactions [23] [43] [44]. Resilience to disaster may be conferred from any level in a geographical community [12] [45]-[47]. Undoubtedly, social awareness and good understanding of the social networks upgrade the collective efficacy in risk management [42] [43]. Walker et al. [21] and others [12] [47] argue that participatory approach upgrade the resilience because people understand the relation between spatial levels in the functioning social and ecological systems as demonstrated [21] [24] [41] [42]. Bristow and Healy [46] claim that human agency is an important factor to regional resilience. We can witness that the director of regional agency (DREAL) and the president of the Syndicat Mixte of the urban community whose territory we studied claimed that driving such a study with face-to-face interviews changed the opinion of the stakeholders, providing an increase of the awareness and the necessity of the solidarities, providing a way to resilience.

\section{Acknowledgements}

The authors would like to thank Mrs Marie-Pierre Collin-Huet, Associate director of the Department of Risk 
Prevention of the DREAL of Franche-Comté. The authors would also like to thank students of the DDMEG Master at Paris 1 Panthéon-Sorbonne University (Marion Adda, Mathilde Bavoil-Mercadier, Anne Behlouli, Sabrina Berrah, Claire Bour, Yakouta Cheniki, Camille Crampé, Raphael Desrosiers, Heloïse Drochon, Daphne Erdal, Charles Etienne, Amalia Ghémard, Lucy Howarth, Julien Huau, Stephanie Huynh, Anahid Kasbarian, Estelle Lefevre, Eddy Loo, Tess Pozzi, Hristina Radivoeva, Mireille Sotelo, Celine Truffier and Alban Wendling), and Assistant professors Catherine Carré and Cécile Huet, for their help with the survey.

\section{References}

[1] Pech, P., Adda, M., Bavoil-Mercadier, M., Behlouli, A., Berrah, S., Bour, C., Cheniki, Y., Crampe, C., Desrosiers, R., Drochon, H., Duplan, C., Erdal, D., Etienne, C., Ghémard, A., Howarth, L. Huau, J., Huynh, S., Kasbarian, A., Lefevre, E., Loo, E., Pozzi, T., Radivoeva, H., Robin-Chevallier, L., Sotelo, M., Truffier, C. and Wendling, A. (2013) Résilience du territoire du syndicat mixte de l'aire urbaine Belfort-Montbéliard-Héricourt-Delle face aux extrêmes liés à l'inondation et la sécheresse. Rapport final, Convention entre la DREAL de Franche-Comté et l'Université Paris 1 Panthéon-Sorbonne, 85 p.

[2] Azar, D. and Rain, D. (2007) Identifying Population Vulnerable to Hydrological Hazards in San Juan, Puerto Rico. GeoJournal, 69, 23-43. http://dx.doi.org/10.1007/s10708-007-9106-8

[3] De Bruijn, K.M. (2005) Resilience and Flood Risk Management: A Systems Approach Applied to Lowland Rivers. Civil Engineering and Geosciences, Delft University Press, Delft, 210 p.

[4] Dauphine, A. and Provitolo, D. (2007) La résilience: Un concept pour la gestion des risques. Annales de Géographie, 654, 115-125. http://dx.doi.org/10.3917/ag.654.0115

[5] Quarantelli, Q.L. (1998) Major Criteria for Judging Disaster Planning and Managing Their Applicability in Developing Countries. Disaster Research Centre, University of Delaware, Newark.

[6] Perry, R.W. and Lindell, M.K. (2003) Preparedness for Emergency Response: Guidelines for the Emergency Planning Process. Disasters, 27, 336-350. http://dx.doi.org/10.1111/j.0361-3666.2003.00237.x

[7] Short, M., Jones, C., Carter, J., Baker, M. and Wood, C. (2004) Current Practice in the Strategic Environmental Assessment of Development Plans in England. Regional Studies, 38, 177-190. http://dx.doi.org/10.1080/0034340042000190154

[8] Hassel, H. (2012) Risk and Vulnerability Analysis in Practice: Evaluation of Analyses Conducted in Swedish Municipalities. Natural Hazards, 63, 605-628. http://dx.doi.org/10.1007/s11069-012-0172-y

[9] Durrant, J.O. and Shummay, J.M. (2004) Attitudes toward Wilderness Study Areas: A Survey of Six Southeastern Utah Counties. Environmental Management, 33, 271-283. http://dx.doi.org/10.1007/s00267-003-3019-1

[10] Handmer, J. (2007) Global Flooding. In: Stoltman, J.P., Lidstone, L. and DeChano, L.M., Eds., International Perspectives on Natural Disasters. Advances in Natural and Technological Hazards Research, Springer, Volume 21: 87-106. http://dx.doi.org/10.1007/978-1-4020-2851-9 4

[11] Pech, P., Diziere, S., Gillet, A.-G., Sureau, C. and Tichit, M. (2010) Environmental Conservation and the Production of New Territories: The Example of French Départements. GeoJournal, 75, 149-161. http://dx.doi.org/10.1007/s10708-009-9259-8

[12] Gupta, J., Akhmouch, A., Cosgrove, W., Hurwitz, Z., Maestu, J. and Unver, O. (2013) Policymakers’ Reflections on Water Governance Issues. Ecology and Society, 18, 35. http://dx.doi.org/10.5751/ES-05086-180135

[13] Ferrier, N. and Haque, C.E. (2003) Hazards Risk Assessment Methodology for Emergency Managers: A Standardized Framework for Application. Natural Hazards, 28, 271-290. http://dx.doi.org/10.1023/A:1022986226340

[14] Auerswald, P., Branscomb, L., LaPorte, T. and Michel-Kerjan, E.O. (2006) Seeds for Disaster, Roots of Response: How Private Action Can Reduce Public Vulnerability. Cambridge University Press, New York, 504 p.

[15] IRGC (2009) Risk Governance Deficits-An Analysis and Illustration of the Most Common Deficits in Risk Governance. International Risk Governance Council, Geneva.

[16] Bradford, R.A., O’Sullivan, J.J., van der Craats, M., Krywkow, J., Rotko, P., Aaltonen, J., Bonaiuto, M., De Dominicis, S., Waylen, K. and Schelfaut, K. (2012) Risk Perception: Issues for Flood Management in Europe. Natural Hazards and Earth System Sciences, 12, 2299-2309. http://dx.doi.org/10.5194/nhess-12-2299-2012

[17] Manyena, S.B. (2006) The Concept of Resilience Revisited. Disasters, 30, 433-450. http://dx.doi.org/10.1111/j.0361-3666.2006.00331.x

[18] Prosser, B. and Peters, C. (2010) Directions in Disaster Resilience Policy. The Australian Journal of Emergency Management, 25, 8-11.

[19] Carpenter, S.R., Walker, B., Anderies, M.J. and Abel, N. (2001) From Metaphor to Measurement: Resilience of What to What? Ecosystems, 4, 765-781. 
[20] Holling, C.S. (2001) Understanding the Complexity of Economic, Ecological and Social Systems. Ecosystems, 4, 390-405. http://dx.doi.org/10.1007/s10021-001-0101-5

[21] Walker, B., Carpenter, S., Anderies, J., Abel, N., Cumming, G., Janssen, M., Lebel, L., Norberg, J., Peterson, G.D. and Pritchard, R. (2002) Resilience Management in Social-Ecological Systems: A Working Hypothesis for a Participatory Approach. Conservation Ecology, 6, 14. http://www.consecol.org/vol6/iss1/art14

[22] Cumming, G.S., Barnes, G., Perz, S., Schmink, M., Sieving, K.E., Southworth, J., Binford, M., Holt, D., Stickler, C. and Van Holt T. (2005) An Exploratory Framework for the Empirical Measurement of Resilience. Ecosystems, 8, 975-987. http://dx.doi.org/10.1007/s10021-005-0129-z

[23] Boon, H.J., Cottrell, A., King, D., Stevenson, R.B. and Millar, J. (2012) Bronfenbrenner's Bioecological Theory for Modelling Community Resilience to Natural Disasters. Natural Hazards, 60, 381-408. http://dx.doi.org/10.1007/s11069-011-0021-4

[24] Bosher, L., Dainty, A., Carrillo, P., Glass, J. and Price, A. (2009) Attaining Improved Resilience to Floods: A Proactive Multi-Stakeholder Approach. Disaster Prevention and Management, 18, 9-22. http://dx.doi.org/10.1108/09653560910938501

[25] Bardsley, D. and Pech, P. (2011) Defining Spaces of Resilience within the Neoliberal Paradigm: Could French Land Use Classifications Guide Support for Risk Management within an Australian Regional Context? Human Ecology, 40, 129-143.

[26] Winter, M.G. and Bromhead, E.N. (2012) Landslide Risk: Some Issues That Determine Societal Acceptance. Natural Hazards, 62, 169-187. http://dx.doi.org/10.1007/s11069-011-9987-1

[27] Sahal, A., Leone, F. and Peroche, M. (2013) Complementary Methods to Plan Pedestrian Evacuation of the French Riviera's Beaches in Case of Tsunami Threat: Graph- and Multi-Agent-Based Modeling. Natural Hazards Earth Science, 13, 1735-1743. http://dx.doi.org/10.5194/nhess-13-1735-2013

[28] Nirupama, N. and Simonovic, S.P. (2007) Increase of Flood Risk Due to Urbanisation: A Canadian Example. Natural Hazards, 40, 25-41. http://dx.doi.org/10.1007/s11069-006-0003-0

[29] Pech, P. (2010) Les cadres de la gestion des risques dans les très grandes métropoles. In: Cros, M., Gaultier-Gaillard, S., Harter, H. and Pech, P., Coord., Catastrophes et risques urbains. Nouveaux concepts, nouvelles réponses, Lavoisier, Paris, 35-43.

[30] Torre, A. and Rallet, A. (2005) Proximity and Localization. Regional Studies, 39, 47-59. http://dx.doi.org/10.1080/0034340052000320842

[31] Dantas, A. and Seville, E. (2006) Organisational Issues in Implementing an Information Sharing Framework: Lessons from the Matata Flooding Events in New Zealand. Journal of Contingencies and Crisis Management, 14, 38-52. http://dx.doi.org/10.1111/j.1468-5973.2006.00479.x

[32] Hovardas, T. and Poirazidis, K. (2007) Environmental Policy Beliefs of Stakeholders in Protected Area Management. Environmental Management, 39, 515-525. http://dx.doi.org/10.1007/s00267-006-0053-9

[33] Brody, S.D. (2003) Measuring the Effects of Stakeholder Participation on the Quality of Local Plans Based on the Principles of Collaborative Ecosystem Management. Journal of Planning Education and Research, 22, 407-419. http://dx.doi.org/10.1177/0739456X03022004007

[34] Hare, M.P., Letcher, R.A. and Jakeman, A.J. (2003) Participatory Modelling in Natural Resource Management: A Comparison of Four Case Studies. Integrated Assessment, 4, 62-72. http://dx.doi.org/10.1076/iaij.4.2.62.16706

[35] Blackstock, K.L., Kelly, G.J. and Horsey, B.L. (2007) Developing and Applying a Framework to Evaluate Participatory Research for Sustainability. Ecological Economics, 60, 726-742. http://dx.doi.org/10.1016/j.ecolecon.2006.05.014

[36] Reed, M.S. (2008) Stakeholder Participation for Environmental Management: A Literature Review. Biological Conservation, 141, 2417-2431. http://dx.doi.org/10.1016/j.biocon.2008.07.014

[37] Rudel, T.K. (2011) Local Actions, Global Effects? Understanding the Circumstances in Which Locally Beneficial Environmental Actions Cumulate to Have Global Effects. Ecology and Society, 16, 19. http://www.ecologyandsociety.org/vol16/iss2/art19/

[38] Chia, J. (2010) Engaging Communities before an Emergency: Developing Community Capacity through Social Capital Investment. The Australian Journal of Emergency Management, 25, 18-22.

[39] Pahl-Wostl, C. (2006) The Importance of Social Learning in Restoring the Multifunctionality of Rivers and Floodplains. Ecology and Society, 11, 10. http://www.ecologyandsociety.org/vol11/iss1/art10/

[40] Lorant-Plantier, E. and Pech, P. (2011) De nouveaux outils dans la gestion du risque inondation en France vecteurs de territorialité? L'exemple du projet de l'Entente Oise-Aisne bassin versant de l'Oise. Annales de Géographie, 678, 193-203. http://dx.doi.org/10.3917/ag.678.0193 
[41] Adger, W.N. (2000) Social and Ecological Resilience; Are They Related? Progress in Human Geography, 24, 347364.

[42] Beall, J. (2001) From Social Networks to Public Action in Urban Governance: Where Does Benefit Accrue? Journal of International Development, 13, 1015-1021.

[43] Pelling, M. (2007) Learning from Others: The Scope and Challenges for Participatory Disaster Risk Assessment. Disasters, 31, 373-385. http://dx.doi.org/10.1111/j.1467-7717.2007.01014.x

[44] Colten, C.E., Kates, R.W. and Laska, S.B. (2008) Three Years after Katrina: Lessons for Community Resilience. Environment, 50, 36-47. http://dx.doi.org/10.3200/ENVT.50.5.36-47

[45] Cottrell, A. and King, D. (2010) Social Assessment as a Complementary Tool to Hazard Risk Assessment and Disaster Planning. Australasian Journal of Disaster and Trauma Studies, 1.

[46] Bristow, G. and Healy, A. (2014) Regional Resilience: An Agency Perspective. Regional Studies, 48, 923-935. http://dx.doi.org/10.1080/00343404.2013.854879

[47] Fraser, E.D.G., Dougill, A.J., Mabee, W.E., Reed, M. and McAlpine, P. (2006) Bottom up and Top Down: Analysis of Participatory Processes for Sustainability Indicator Identification as a Pathway to Community Empowerment and Sustainable Environmental Management. Journal of Environmental Management, 78, 114-127.

http://dx.doi.org/10.1016/j.jenvman.2005.04.009 